\title{
DOENÇAS CAUSADAS POR VÍRUS NA CULTURA DE FEIJOEIRO (Phaseolus vulgaris L.)
}

\author{
${ }^{\bullet}$ Felipe Rafael Garcés Fiallos \\ Unidad de Investigación Cientifica y Tecnológica, Universidad Técnica Estatal de Quevedo, km 7 vía \\ Quevedo - El Empalme, C. P. 73. Mocache,Los Ríos, Ecuador. ${ }^{\triangleright}$ felipegarces23@yahoo.com
}

\section{RESUMO}

$\mathrm{O}$ feijoeiro é atacado, além de fungos, nematóides e bactérias, por vírus que podem causar danos e perdas numa lavoura. As doenças causadas por vírus têm exercido um papel relevante na baixa produtividade do feijoeiro no Brasil e outros países Latino-Americanos. Os métodos de controle para as viroses de plantas cultivadas são, em geral, muito restritos. Pela falta desta informação e pela importância da cultura do feijão, se traz esta revisão, onde são relatadas as doenças virais mais importantes desta cultura dentro do Brasil e fora dele, explicando detalhadamente sua sintomatologia, etiologia e seu controle. As doenças viróticas mais importantes no feijoeiro no Brasil são o bean common mosaic virus (BCMV), bean golden mosaic virus (BGMV), bean rugose mosaic virus (BRMV), cowpea mild mottle virus (CpMMV) e southern bean mosaic virus (SBMV). Esta revisão traz o mais importante em relação às doenças primordiais causadas por vírus de plantas na cultura de feijão.

Palavras chave: Phaseolus vulgaris L., vírus, manejo e controle.

INTRODUÇão

A família Fabaceae é constituída por muitos gêneros e espécies, sendo umas das principais a soja [Glycine max (L.) Merrill], e o feijão (Phaseolus vulgaris L.) A cultura do feijão é uma das leguminosas mais semeadas, sendo de grande importância econômica no Brasil, atingindo uma área nacional semeada na primeira e segunda safra de 2008 / 2009 de 1.44 e 1.97 milhões de hectares, respectivamente (CONAB, 2009), com produção média estimada a nível nacional de 830 kg.ha-1 ${ }^{-1}$ sendo $7.2 \%$ superior à safra passada (IBGE, 2009).

No Brasil o feijão é utilizado na alimentação básica, sendo assim que esse país é o maior produtor mundial e o maior consumidor, seguido da Índia, China, México, Estados Unidos e Uganda (Zuppi et al., 2005). De acordo com Almeida et al. (2005), já foram identificadas, aproximadamente, 40 doenças na cultura da soja no Brasil, sendo que seis são causadas por vírus. O feijoeiro é atacado além de fungos, nematóides e bactérias, por vírus que podem causar danos e perdas numa lavoura. As doenças causadas por vírus têm

Recibido: 30-Mayo-2010. Recibido en forma corregida: 2-Agosto-2010. Aceptado: 2-Agosto-2010.

Publicado como ARTÍCULO DE REVISIÓN en Ciencia y Tecnología 3(2): 1-6. 2010
Abstract

$\mathrm{T}$ he bean is attacked, in addition to fungi, nematodes and bacteria, by a virus that can cause injury and loss on a crop. The diseases caused by viruses have played a role in the low productivity of beans in Brazil and other Latin-American countries. The control for viral diseases of cultivated plants is in general, very limited. For lack of this information and for the importance of culture, it brings this review, where the most important diseases caused by viruses in bean, within Brazil and abroad, detailing their symptoms, etiology and control are described. The virus related whit the most important diseases in Brazil are the bean common mosaic virus (BCMV), bean golden mosaic virus (BGMV), bean rugose mosaic virus (BRMV), cowpea mild mottle virus (CpMMV) and southern bean mosaic virus (SBMV). This review describes the principal aspects related to the most important diseases caused by plant viruses in common bean crop.

Key words: Phaseolus vulgaris L., virus, management and control. exercido um papel relevante na baixa produtividade do feijoeiro no Brasil, e outros países Latino-Americanos, sendo as mais numerosas as ocasionadas por fungos seguindo-se as de etiologia viral, algumas tendo adquirido expressiva importância econômica (Gamez, 1977).

Os métodos de controle para as viroses de plantas cultivadas são muito restritos. Pela falta desta informação e pela importância da cultura do feijão, se traz esta revisão, onde são relatadas as doenças mais importantes da cultura causadas por vírus, dentro do Brasil e fora dele, explicando detalhadamente sua sintomatologia, etiologia e seu controle.

As doenças causadas por vírus mais importantes no feijoeiro no Brasil são o bean common mosaic virus (BCMV), bean golden mosaic virus (BGMV), bean rugose mosaic virus (BRMV), cowpea mild mottle virus (CpMMV) e southern bean mosaic virus (SBMV).

\section{Mosaico comum do feijoeiro - Bean common mosaic vírus (BCMV)}

$\mathrm{O}$ primeiro reporte do mosaico comum do feijoeiro, foi nos Estados Unidos de América no ano 1917 (Hall, 1991). Antes do aparecimento de variedades 
Garcés.

resistentes, o mosaico comum era a doença virótica de maior importância econômica para a cultura do feijoeiro, atingindo uma incidência de 50 até próximo de 100 \% (Bianchini et al., 2005). Esta doença afeta, principalmente, o feijão francês, embora também outras espécies de feijão (Agrios, 2005).

\section{Sintomatologia}

Bianchini et al. (2005), menciona que compreende mosaico foliar acompanhando as nervuras. Quando os sintomas são mais severos, ocorre formação de bolhas nas áreas verdes escuras, enrolamento, retorcimento e diminuição de tamanho dos folíolos. Existe também uma necrose sistêmica, se caracterizando por uma necrose vascular, evoluindo do ápice para a base da planta, descoloração do caule e necrose das nervuras nos folíolos, seguida da morte apical e morte da planta

\section{Etiologia}

Causado pelo Bean commom mosaic virus (BCMV), pertencente à família Potyviridae, gênero Potyvirus, pode causar perdas de 35 a 98\% da produção, dependendo do estádio da planta na época da infecção (Faria et al., 1996). O BCMV possui partículas alongadas flexíveis, medindo 12-15 nm de diâmetro e 720-770 nm de comprimento e seu ácido nucléico é do tipo RNA de fita simples (Bianchini et al., 2005). O mesmo autor relata que a transmissão é por sementes, mecanicamente de planta a planta e por pulgões, sendo este o vetor desta doença, com forma de transmissão não persistente.

\section{Controle}

O controle do vírus do mosaico comum, deve ser iniciado com a escolha da cultivar (resistente) e da semente (de boa qualidade fitossanitária) a ser utilizada para semeadura (Hall, 1991). Reis et al. (2007), relatam, também, a eliminação de plantas doentes e controle do vetor.

\section{Mosaico dourado do feijoeiro - Bean golden mosaic virus (BGMV)}

O mosaico dourado do feijoeiro é a virose mais importante que ocorre no Brasil e é causado pelo bean golden mosaic virus (BGMV), família Geminiviridae, gênero Begomovirus (Gasparin et al., 2005). O mesmo autor menciona que no Estado do Paraná têm sido observadas infecções simples do BGMV, ou infecções mistas, tanto com espécies de outros geminivirus, como com vírus isométricos, destacando-se o bean rugose mosaic virus (BRMV), família Comoviridae, gênero Comovirus. Provoca danos que podem variar de 30 a $100 \%$, dependendo do cultivar, estádio da planta, população do vetor, presença de hospedeiros alternativos e condições ambientais (Faria et al., 1996). Este vírus tem uma restrita gama de hospedeiros, confinada quase que, exclusivamente, a espécies da família das leguminosas, sendo algumas de interesse econômico como o feijoeiro comum e a soja (Moreira e Gaspar, 2002). Pode atingir também, espécies como chícharo, trevo, ervilha, acácia preta, gladíolo e abóbora amarela (Agrios, 2005).

\section{Sintomatologia}

As infecções mistas ocorrem principalmente na safra da seca, período em que se observa maior incidência do BGMV. Os danos provocados nestes casos são mais severos que aqueles causados pelas infecções individuais por qualquer um dos vírus (Gasparin et al., 2005).

Os sintomas mais predominantes são o mosaico amarelo intenso em todo o limbo foliar, podendo ocorrer nanismo, encurtamento de entre-nós, perda de dominância apical e brotamento das gemas axilares (Furlan, 2004). Há, também, que assinalar que os sintomas incitados pela mosca branca transmissíveis por este Begomovirus incluem intensa clorose foliar, deformação das vagens e atrofiamento das plantas (Galvez e Morales, 1994).

O principal sintoma celular é a mudança da morfologia dos cloroplastos, especialmente no sistema lamelar, mas podem ocorrer sintomas também nos tecidos do floema e células adjacentes ao parênquima. Também, ocorre aumento de tamanho do nucléolo, que se condensa em regiões granulares fibrilares, e mais tarde toma a forma de anéis, de tamanho e número variados por núcleo (Lemos et al., 2003). Finalmente, quando partículas virais aparecem no núcleo, a capacidade de translocação de solutos na planta é dificultada, afetando a produtividade do feijoeiro (Faria et al., 1996).

\section{Etiologia}

O mosaico dourado, doença causada por um geminivírus, é um dos principais problemas na cultura do feijão na América Latina (Galvez e Morales, 1989). Furlan (2004) considera que as condições favoráveis são uma temperatura elevada, ao redor de $30^{\circ} \mathrm{C}$. e baixa umidade (aumento da população do vetor). O mesmo autor menciona que o vetor é Bemisia tabaci (mosca branca) biótipos A e B. O vírus é detectado mediante técnicas de hibridização de ácidos nucléicos (Gilbertson et al., 1991). 


\section{Controle}

A resistência ao BGMV pode ser controlada pela adição de genes em linhagens suscetíveis, por cruzamentos dialélicos ou não, seguida de sucessivas gerações de autofecundação e presença do vírus. Deve-se lembrar que outras características de mercado como tamanho, aparência da semente, paladar, porte e precocidade da planta, também, devem ser levadas em consideração e poderão alterar a classificação das progênies selecionadas na condução de experimentos futuros (Juliatti et al., 2005).

Rodrigues et al. (1997), constataram que a diminuição do número de moscas brancasé proporcionalà queda da temperatura. Assim, estes autores recomendam efetuar a semeadura do feijão nas águas, no período de Outubro a Novembro e, no Outono-Inverno, da segunda quinzena de Abril até Agosto, quando a população de mosca branca é mais baixa. Na safra da seca, a época de semeadura preferível vai do início de Janeiro a Março.

Boiça Júnior et al. (2000), avaliaram o controle de B. tabaci com inseticidas Fosfamidom 500 e Metamidophos BR, na dose de $0.5 \mathrm{~L} \mathrm{ha-}^{1}$, em diferentes cultivares de feijoeiro, semeadas na época de Inverno (Maio) de 1999, e constataram que o inseticida controlou a incidência do inseto vetor em todas as cultivares, proporcionando incrementos na produção de grãos.

A mosca branca B. argentifolii é também vetor do vírus do mosaico dourado do feijoeiro, variando a eficiência da transmissão de cultivar para cultivar, devido, provavelmente, à diferença na resistência dos materiais testados (Yuki et al., 1998). O controle químico do vetor é apenas parcialmente eficaz, pois o aumento dos custos de produção impede o uso de inseticidas, sendo que para a maioria dos pequenos produtores de feijão será muito limitado (Osorno et al., 2007).

\section{Mosaico rugoso do feijoeiro - Bean rugose mosaic virus (BRMV)}

O mosaico rugoso do feijoeiro, causado pelo bean rugose mosaic virus (BRMV), foi relatado pela primeira vez no Brasil em São Paulo (Camargo et al., 1969). A presença desta virose tem sido observada com freqüência, em grande parte de regiões produtoras do Cerrado e do Paraná (Bianchini et al., 2005).

\section{Sintomatologia}

O mosaico rugoso caracteriza-se por faixas simétricas verde-escuras ou normais, nas nervuras, e áreas verde - claras, entre as nervuras (Bianchinin et al., 2005), existindo também, um enrugamento com leves características de mosaico e deformação nas folhas (Hall, 1991).

\section{Etiologia}

O bean rugose mosaic virus (BRMV) pertence à família Comoviridae, gênero Comovirus (Gasparin et al., 2005), podendo existir em infecções mistas, com espécies de outros Begomovirus, como é o bean common mosaic virus.

O genoma dos Comovírus é composto por duas moléculas de RNA de fita simples, sentido positivo, encapsuladas separadamente em partículas icosaédricas com diâmetro de 28 a $30 \mathrm{~nm}$. Os dois RNAs possuem uma proteína viral (VPg) ligada covalentemente às suas extremidades 5', e uma cauda poli-A nas extremidades 3' (Castillo-Urquiza et al., 2006).

Atransmissãoé feita por besouros crisomelídeos das espécies Cerotoma arcuata e Diabrotica speciosa, numa relação do tipo persistente (Bianchini et al., 2005). Este vírus não é transmitido via semente em feijoeiro ou soja (Martins et al., 1994), mas é facilmente transmitido via extrato vegetal tamponado (Castillo-Urquiza et al., 2006).

\section{Controle}

Não há recomendação de medidas especificas para o controle do mosaico rugoso do feijoeiro. As alternativas possíveis são evitar o plantio próximo de prováveis fontes de vírus, como lavouras de soja ou feijoeiro, que contenham o vírus ou inseto vetor, e controlar quimicamente os insetos vetores logo no início do desenvolvimento das plantas (Bianchini et al., 2005).

\section{Mosaico angular amarelo - Cowpea mild mottle virus (CpMMV)}

O mosaico angular amarelo, tem sido atualmente de grande importância econômica por ter causado danos severos, incluindo até a morte das plantas infectadas (Almeida et al., 2005). O mosaico angular amarelo foi descrito pela primeira vês em Brasil na cultivar Jalo (Costa et al., 1980). Recentemente, foi detectado em campos de feijão, cv. Alubia, na região da Província de Salta, ao norte da Argentina, causando sintomas de clorose e de mosqueado fraco nas plantas da leguminosa (Pardina et al., 2004). Provocado pelo cowpea mild mottle virus (CpMMV) tem como principais leguminosas suscetíveis as espécies: Arachis hypogea L., Canavalia ensiformis D.C., Cyamopsis tetragonalobus Taub., Dolichos lab lab L., Glycine max (L.) Merril., Macroptilium lathyroides Urb., Phaseolus 
Garcés.

acutifolius A. Gray, P. longepedunculatus Mart., P. lunatus L., P. vulgaris L., Pisum sativum L., Stizolobium deeringianum Bart (sin. Mucuna deeringiana), Stizolobium sp. e Vigna unguiculata (L.) Walp. (Costa et al., 1983).

\section{Sintomatologia}

$\mathrm{Na}$ safra agrícola de 2000/2001 foram constatados sintomas de necrose da haste, causando seca e morte de plantas de soja, na região de Morrinhos e Goiatuba, GO (Marubayashi, 2006). Também ocorre mosaico e necrose nas folhas das plantas de feijão e murchamento nas plantas (Hall, 1991).

\section{Etiologia}

Em preparações elaboradas conforme a técnica de "leaf dip", a partir de folhas infectadas com CpMMV em feijoeiro Jalo, com observações ao microscópio eletrônico de transmissão, foi detectada a presença de partículas alongadas com tamanho de $630 \mathrm{~nm}$ de comprimento por $13 \mathrm{~nm}$ de largura (Gaspar \& Costa, 1993). Baseados na ausência de cata-ventos e de outras inclusões virais e pelo fato de haver uma tendência de constatação de sintomas causados pelo CpMMV como extremamente fracos ou até mesmo, dele ser latente em muitas variedades de feijoeiros, os autores concluíram ser esse vírus pertencente ao gênero Carlavirus.

Acredita-se que existem diversas estirpes do CpMMV, sendo que uma tem sido mais severa em comparação com os resultados de trabalhos anteriores, pois as reduções na produtividade nunca foram inferiores aos $85 \%$, quando variedades suscetíveis eram infectadas pelo vírus (Almeida et al., 2003), podendo ser até mesmo de 100\% (Hoffmann et al., 2003).

A mosca branca Bemisia. tabaci é o principal vetor do CpMMV, podendo um inseto apenas transmitir o vírus, sendo, também facilmente transmitido por inoculação mecânica (Costa et al., 1980, 1983).

\section{Controle}

A população da mosca branca está diretamente relacionada com a maior taxa de transmissão do vírus, pelo que, pode-se reduzir a incidência do CpMMVem culturas suscetíveis com o controle eficiente desse vetor (Marubayashi, 2006).

\section{Mosaico do sul ou meridional do feijoeiro - Southern bean mosaic (SBMV)}

O mosaico do sul ou meridional do feijoeiro, provocada pelo southern bean mosaic virus (SBMV), foi reportada por primeira vez em feijão nos Estados Unidos de América, no ano 1943, sendo depois referenciada na França e América Latina (Hall, 1991). No Brasil, foi detectada pela primeira vez em feijoeiros (Phaseolus vulgaris L.), na região do Distrito Federal, ocasionando sintomas de mosaico fraco a severo, deformação da vagem e distorção foliar (Cupertino et al., 1982). É conhecido que este vírus tem glicoproteínas, tal como o tobacco necrosis virus (TNV) e tobacco mosaic virus (TMV) (Kimmins e Brown, 1975).

\section{Sintomatologia}

Ocasiona sintomas de mosaico fraco a severo, deformação da vagem e distorção foliar (Cupertino et al., 1982), podendo também, causar manchas necróticas circulares nas folhas e deformação e redução nas sementes, embora a redução nas sementes tenha pouca ocorrência (Hall, 1991).

\section{Etiologia}

Pertencente ao gênero Sobemovirus (Van Regenmortel et al., 2000), o SBMV possui partículas isométricas (28-30 nm), contendo RNA genômico de 4-4.5 $\mathrm{Kb}$ envolto por proteína capsidial com massa molecular de 29-39 kDa (Sehgal, 1981). Este vírus tem uma restrita gama de hospedeiros, confinada quase, que exclusivamente, a espécies da família das leguminosas, sendo algumas de interesse econômico como o feijoeiro comum e a soja (Moreira e Gaspar, 2002). Tem como vetor os afídeos (Hall, 1991).

\section{Controle}

Pode ser com a seleção de variedades resistentes de feijão, sendo provavelmente esta a medida mais efetiva para controlar a disseminação numa região. Poderá ser também eficaz a alternativa do controle de afídeos vetores, embora seja uma medida criticamente avaliada (Hall, 1991).

\section{LiTERATURA CITADA}

Agrios, G. N. 2005. Fitopatologia. 2da. Edicao. Ed. Limusa. México.

Almeida, A. M. R., L. P. Ferreira, J. T. Yorinori, J. F. V. Silva, A. A. Henning, C. V. Godoy, L. M. Costamilan e M. C. Meyer. 2005. Doenças da soja (Glycine max). In: Kimati, H., L. Amorim, J. A. M. Rezende, A. Bergamin Filho e L. E. A. Camargo. Vol. 2. (4 Ed.). Manual de Fitopatologia. São Paulo, Agronômica Ceres. P 569. 
Almeida, A. M. R., M. C. Meyer, L. A. Almeida, E. W. Kitajima, R. A. Guerzoni e J. Jr. Nunes. 2003. Severidade da necrose da haste. Cultivar: Grandes Culturas 56: 26-28.

Bianchini, A., A. C. Maringoni e S. M. T. P. G. Carneiro. 2005. Doenças do feijoeiro (Phaseolus vulgaris). In: Kimati, H., L. Amorim, J. A. M. Rezende, A. Bergamin Filho e L. E. A. Camargo. Vol. 2. (4 Ed.). Manual de Fitopatologia. São Paulo, Agrônomica Ceres. P 333.

Boiça Júnior, A. L., T. M. Santos e M. J. Moçouçah. 2000. Adubação e inseticidas no controle de Empoasca kraemeri e Bemisia tabaci, em cultivares de feijoeiro semeados no Inverno. Scientia Agricola 57 (4): 635-641.

Camargo, I. J. B., E. W. Kitajima, e A. S. Costa. 1969. Inclusões cristalinas de um vírus isodiamétrico que afeta o feijoeiro. Ciência e Cultura 21:490.

Castillo-Urquiza, G. P., F. G. M. Maia, M. G. Carvalho, C. M. F. Pinto. e F. M. Zerbini. 2006. Caracterização de um isolado do bean rugose mosaic virus (BRMV) de Minas Gerais e estimativa de perdas em feijoeiro em infecção simples ou em conjunto com o BCMV. Fitopatologia Brasileira 31:455461.

CONAB. 2009. Companhia Nacional de Abastecimento. Acompanhamento da safra Brasileira. Grãos safra 2008/2009. http://www.conab.gov.br/conabweb/ download/safra/8graos_08.09.pdf (consultado a 12 de Maio de 2009).

Costa, A. S., J. O. Gaspar e J. Vega. 1980. Mosaico angular do feijoeiro jalo causado por um vírus do grupo $\mathrm{S}$ transmitido por mosca branca. In: Resumos do I Seminário Sobre Pragas e Doenças do Feijoeiro, Campinas.

Costa, A. S., J. O. Gaspar e J. Veja. 1983. Mosaico angular do feijoeiro Jalo causado por um "Carlavirus" transmitido pela mosca branca Bemisia tabaci. Fitopatologia Brasileira 8(2):325-337.

Cupertino, F. P., M. T. Lin, E. W. Kitajima e C. L. Costa. 1982. Occurrence of southern bean mosaic virus in central Brazil. Plant Disease 66:742-743.

Faria, J. C., J. R. N. Anjos, A. F. Costa, C. A. Sperâncio e C. L. Costa. 1996. Doenças causadas por vírus e seu controle. In: Araujo, R. S., C. A., Rava, L. F. Stone e M. J. O. Zimmermann. (Eds.). Cultura do Feijoeiro Comum no Brasil. Piracicaba: Potafos. P 731.

Furlan, S. H. 2004. Doenças Bióticas e Abióticas do Feijoeiro. Guia de Identificação e Controle de Doenças do Feijoeiro. APTO-Instituto Biológico.

Galvez, G. E. e F. J. Morales. 1989. Whitefly transmitted viruses. In: Schwartz, H. F. e M. A. Pastor Corrales. (Ed.). Bean Production Problems in the
Tropics. Cali: Centro Internacional de Agricultura Tropical. P 379.

Galvez, G. E. and F. J. Morales. 1994. Virus transmitidos por la mosca blanca, p. 435-464. Citado por Osorno, J. M., J. S. Beaver, F. Ferwerda and P. N. Miklas. 2003. Two genes from Phaseolus coccineus L. confer resistance to bean golden yellow mosaic virus. Ann. Rep. Bean Improv. Coop. 46:147-148.

Gamez, R. 1977. Las enfermedades virales como factores limitantes em la produccion de frijol (Phaseolus vulgaris L.) en America Latina. Fitopatologia 12:24-26.

Gaspar, J. O. e A. S. Costa. 1993. Efeito do vírus do mosaico angular sobre o metabolismo de carboidratos em feijoeiro Jalo. Fitopatologia Brasileira 18(4):541-544.

Gasparin, M. D. G., A. Bianchini, E. R. Souto, J. O. Gaspar, A. M. R. Almeida e E. W. Kitajima. 2005. Detecção do southern bean mosaic virus no Paraná e separação do bean rugose mosaic virus em feijoeiro. Fitopatologia Brasileira 30:75-78.

Gilbertson, R. L., J. C. Faria, S. F. Hanson, F. J. Morales, P. Ahlquist, D. P. Maxwell and D. R. Russel. 1991. Cloning of the complete DNA of four bean-infecting geminiviruses and determinig their infectivity by electric discharge particle acceleration. Phytopathology 81: 980-985.

Hoffmann, L. L., T. D. Nora, M. A. R. Oliveira de e A. M. R. Almeida. 2003. Doenças da soja: necrose da haste. Coodetec, Disponível em http://www. coodetec. com. br/artigos.htm (consultado a 28 de Setembro de 2009).

Hall, R. 1991. Compendium of bean diseases. APS Press.

IBGE 2009. Instituto Brasileiro de Geografia e Estatística.. Lavouras. Produção de cereais, leguminosas e oleaginosas. http://www.ibge.gov. br/home/estatistica/ indicadores/agropecuaria/ 1spa/lspa_200904comentarios.pdf (consultado a 12 de Maio de 2009).

Juliatti, F. C., S. A. Moraes, H. D. Silva e M. H. C. Borges. 2005. Seleção de progênies de feijoeiro F4 resistentes ao bean golden mosaic virus. Fitopatologia Brasileira 30:279-285.

Kimmins, W. C. and R. G. Brown. 1975. Effect of a non-localized infection by southern bean mosaic virus on a cell wall glycoprotein from bean leaves. Phytopathology 65:1350-1351.

Lemos, L. B., D. F. Fornasieri, T. R. V. Silva e R. P. Sorattode. 2003. Suscetibilidade de genótipos de feijão ao vírus-do-mosaico-dourado. Pesquisa Agropecuária Brasileira, Brasília 38(5): 575-581.

Martins, T. R., A. M. R. Almeida, L. A. Almeida, A. Nepomuceno, C. M. Chagas e J. F. F. Toledo. 
1994. Sinergismo observado em plantas de soja infectadas pelos vírus do mosaico comum da soja e do mosaico-em-desenho do feijoeiro. Fitopatologia Brasileira 19:430-436.

Marubayashi, J. M. 2006. Cowpea mild mottle virus: Transmissão, círculo de hospedeiros e resposta à infecção de cultivares IAC de feijão e soja. Dissertação de Mestrado em Agricultura Tropical e Subtropical. Instituto Agronômico de Campinas, São Paulo. P 29.

Moreira, A. E. e J. O. Gaspar. 2002. Propriedades moleculares de um isolado brasileiro do southern bean mosaic virus. Fitopatologia Brasileira 27:292-297.

Osorno, J. M., J. S. Beaver, F. Ferwerda and P. N. Miklas. 2007. Two genes from Phaseolus coccineus L. confer resistance to bean golden yellow mosaic virus. Ann. Rep. Bean Improv. Coop. 46: 147148.

Pardina, P. E. R., J. D. Armeodo, G. A. Truol, P. S. Herrera and I. G. Laguna. 2004. First Record of cowpea mild mottle vírus in bean crops in Argentina. Australasian Plant Pathology 33(1): 129-130.

Reis, E. M., C. A. Reis e C. A. Forcelini. 2007. Manual de Fungicidas. Guia para o controle de doenças de plantas. Resumo de medidas no controle efetivas segundo as classes de doenças.
Rodrigues, F. de Á., A. C. F. Borges, M. R. dos Santos, J. J. Fernandes e A. de Freitas Júnior. 1997. Flutuação populacional da mosca-branca e a incidência de mosaico dourado em feijoeiro. Pesquisa Agropecuária Brasileira 32(10): 10231027.

Sehgal, O. P. 1981. Southern Bean Mosaic Virus Group. In: Kurstak, P. (Ed.) Handbook of Plant Virus Infections and Comparative Diagnosis. Elsevier/ North Holland. P 91.

Van Regenmortel, M. H. V., C. M. Fauquet, D. H. L. Bishop, E. B. Carstens, M. H. Estes, S. M. Lemon, J. Maniloff, M. A. Mayo, D. J. Mcgeoch, C. R. Pringle and R. B. Wickner. 2000. Virus Taxonomy: seventh report of the International Committee on Taxonomy of Viruses. Academic Press.

Yuki, V. A., A. L. Lourenção, H. Kuniyuki e E. A. Juarez. 1998. Transmissão experimental do vírus do mosaico dourado do feijoeiro por Bemisia argentifolii Bellows \& Perring. Entomol. Brasil. 27(4): 675-678.

Zuppi, M., J. O. M. Menten, L. C. S. Ferreira - Lima, A. A. Rabalho e V. C. Frare. 2005. Produtos fitossanitários utilizados no feijoeiro no Brasil: Evolução e situação atual. In Anais do VIII Congresso Nacional de Pesquisa de Feijão, Goiânia. P 1260 - 1268. 